Published in Pickard, S. (ed), 2014, Anti-Social Behaviour in Britain: Victorian and contemporary perspectives, Palgrave Macmillan reproduced with permission of Palgrave Macmillan.

This extract is taken from the author's original manuscript and has not been edited. The definitive, published, version of record is available here http://www.palgrave.com/page/detail/anti-social-behaviour-in-britain-sarahpickard/?sf1=barcode\&st1=9781137399304 and www.palgraveconnect.com

Greater Expectations: Intolerance and control of public space anti-social behaviour in the $19^{\text {th }}$ and $21^{\text {st }}$ Centuries

\title{
Craig Johnstone
}

\section{Introduction}

One hundred years and very considerable social, economic and cultural change separated the end of the Victorian era and the opening decade of the twenty-first century. Nevertheless, this chapter argues that there are clear parallels between the concerns that fuelled the intense focus on anti-social behaviour (ASB) that characterised Tony Blair's premiership and those that existed throughout much of the nineteenth century, most notably during its middle decades. It is contended that New Labour did not so much 'invent' anti-social behaviour as to draw fresh attention to longstanding concerns by fusing them together under the anti-social behaviour banner or, to borrow Vic Gatrell's (1990: 254) observation on another period, 'Old issues still worried people. Only the language got fancier.' This chapter argues that what particularly links the Victorian and Blair eras was the concern with the use and perceived abuse of public space. The policy solutions to this problem were era-specific, but the outcome was the same: a concerted effort to manage the usage of public space by the removal of signs and symbols of disorder through exclusion or enforcing a modification of proscribed behaviour. Both periods under consideration were noteworthy for the reframing of what constituted acceptable conduct, both in public space and everyday life. Indeed, the chapter views the attention given by policy to what we now know as anti-social behaviour as part of broader disciplinary projects concerned with maintaining order, upholding new definitions of 'normal' behaviour and correcting the faulty morals of what New Labour called the 'hard to reach' ${ }^{1}$, but which the Victorians more commonly condemned as the 'residuum' or 'undeserving poor.' 
In spite of the potentially far-reaching consequences of the wholesale reform and rebranding of anti-social behaviour controls in England and Wales set in train since 2010 by the Conservative-Liberal Democrat coalition government through its 2013 Anti-social Behaviour, Crime and Policing Bill, it is New Labour, and particularly the governments of Tony Blair, that is most closely associated with this social phenomenon. The Crime and Disorder Act 1998 fired the legislative starting gun on anti-social behaviour intervention, but the profile of anti-social behaviour peaked in the period between New Labour's second election victory in 2001 and Blair's resignation as Prime Minister in 2007, which saw the passing into law of the Anti-Social Behaviour Act 2003, the introduction of the Anti-social Behaviour Order (ASBO) 'on conviction' or CRASBO and the launch of the Respect agenda. Post Blair, the rhetoric on anti-social behaviour has become markedly less shrill (Burney, 2009), Labour's flagship anti-social behaviour intervention, the ASBO, has been deployed more and more sparingly with each passing year (Ministry of Justice, 2013), concerns about disorderly conduct have been overtaken since the 2011 riots by worries about youth gangs (Centre for Social Justice, 2012) and more pressing political matters such as the scale of the national debt. The picture could not have been more different during Blair's premiership. New Labour largely constructed the concept of anti-social behaviour as we understand it today, introducing it to the political lexicon. Blair (2010) argues that addressing anti-social behaviour was central to New Labour's vision for society and he, along with his first two Home Secretaries, Jack Straw and David Blunkett, were proactive in developing a narrative about the causes and consequences of anti-social behaviour and the most appropriate methods for tackling it. This was backed up by legislation creating a smorgasbord of new sanctions and criminal justice powers targeted at anti-social acts and individuals (see Squires, 2008; Crawford, 2009a \& 2009b; Millie, 2009 for discussion). New Labour's approach to anti-social behaviour, and the legal instruments it created to convince the irresponsible and disrespectful to change their ways, have received extensive coverage in academic and policy literature during the last 15 years. It is my intention here, therefore, to cover more recent developments relatively sparingly, enabling the chapter to draw out Victorian parallels more fully. The selection of nineteenth and twenty-first century developments for comparison should not be read as a suggestion that disorder in public space was of no concern during the intervening century it simply had particular salience during the two time frames under consideration. 


\section{New Labour and anti-social behaviour: concerns and motivations}

Anti-social behaviour was very imprecisely defined by the Crime and Disorder Act 1998 making it a rather 'catch all' concept. This was intentional, allowing the measures put in place to curb it to be used against all forms of behaviour with the potential to cause 'harassment, alarm and distress,' from minor law breaking, which typically only attracted small penalties in the Magistrates' Courts (Squires, 2008), through to activities that some might consider inconsequential, but to the victim had a significant impact on well-being and quality of life. Much of this behaviour could be characterised as persistent nuisance; the sort of acts that might not attract criminal sanction but were fear-inducing and troubling in their own right (Blair, 2010). Significantly, the Labour government was able to present the concept of anti-social behaviour as new because the activities it defined as problematic had been progressively marginalized within policy and policing over a number of decades, particularly as crime rates accelerated after the 1970s. As David Garland (1996) has noted, 'high crime societies,' amongst which he included Britain, had tended to 'define deviance down' as crime rates rose in order to enable resources to be concentrated on addressing what was considered more serious crime. This translated into less and less attention being paid to everyday disorderly-but-not-strictly-criminal behaviour.

Whilst some anti-social behaviour cases have involved disputes between neighbours or the victimisation of particular people, the Fiona Pilkington case being an especially tragic example ${ }^{2}$, the main target of the mechanisms developed for clamping down on anti-social behaviour was public space disorder. This is evident in legislative solutions. The ASBO, as well as requiring desistance from specified behaviour could also require recipients to stay out of certain geographic areas. The Dispersal Order was specifically designed to remove groups of people, typically the young, from designated places (Crawford, 2009b) whilst the Local Child Curfew Scheme was concerned with the presence of unaccompanied children in public places at night. A suite of orders and the expansion in the use of the fixed penalty fine were also designed to combat the disorder associated with public drunkenness in the nighttime economy (Hadfield, 2006). The measures implemented were not limited to anti-social acts, with the Clean Neighbourhoods and Environment Act 2005 targeting other forms of public space 'abuse' such as the abandoning of vehicles, littering in open spaces and leaflet distribution. To aid in the enforcement of these new rules the role of Police Community 
Support Officer (PCSO) was created by the Police Reform Act 2002 with many thousands of them employed to work with regular police officers in new neighbourhood policing teams, walking the beat to offer reassurance, collect information and enhance surveillance of 'problem' communities. The police and PCSOs were helped in building cases against the anti-social, and enforcing the penalties imposed, by local authority staff and housing officers, who had been empowered by the Crime and Disorder Act 1998, and by the public, who were encouraged by the Together campaign and by the naming and shaming of ASBO recipients to be proactive in ridding their communities of threats to their quality of life (Home Office, 2003; Squires, 2008; Crawford, 2009a).

New Labour's commitment to doing something about anti-social behaviour was driven by a number of interlocking factors. Firstly, it offered a practical remedy to the very real problems that constituents, particularly in poorer inner city communities, were reporting to their Labour MPs (Blair, 2010). Secondly, Blair and other senior ministers had bought into the argument about the importance of order maintenance set out in J.Q. Wilson and George Kelling's (1982) 'Broken Windows' article. Blair captures the crux of their argument in his memoir: 'The concept is this: if you tolerate the small stuff, you pretty soon find the lawbreakers graduate to the high-level stuff. So cut it out at source; tolerate nothing, not even painting a street wall or dropping litter' (2010: 493). The primacy afforded the broken windows perspective by New Labour is evident particularly in the Respect and Responsibility White Paper (Home Office, 2003), which rehearses Wilson and Kelling's arguments almost verbatim. Thirdly, it reinforced the narrative about Labour's tough and serious approach to crime and disorder that Blair started to develop as Shadow Home Affairs spokesman and captured in the now-familiar slogan 'Tough on crime, tough on the cause of crime,' ${ }^{3}$ which went on to become a New Labour mantra. Fourthly, it was also part of a more fundamental reform of a criminal justice system which, Blair argued, was still using nineteenth century means to tackle twenty first century problems (Squires, 2008; Burney, 2009).

\section{From fear and disorder to 'mastering the masterless' in early Victorian Britain}

On first impressions, the problems confronting the political elite in early Victorian Britain appear to be of an entirely different register to those occupying Blair's Labour Party. However, controlling street behaviour was central to the imposition of order in a rapidly urbanising society and played an important role in shaping the industrial working class of 
popular imaginary. The first decades of the Victorian era were characterised by concerns arising from the mass migration of labourers from the countryside to the newly industrialising towns and cities. The speed of change was striking (see Lawless and Brown, 1986; Harrison, 1971 for details) but the laissez-faire state, unwilling to interfere with the free market, was slow to respond to the multiple implications of such fundamental transformation. Of greatest concern to the early Victorian elite was what the urban 'masses' might get up to if new means to govern them were not found and 'a stable pattern of civil and moral order' preserved (Storch, 1977: 138). Their unease peaked in the 1830s and 1840s, when it was feared that Chartist protests would spiral into more general insurrection. According to Robert Storch:

both the actions and the 'language' spoken by urban masses were, if intelligible at all, deeply frightening. The notion that the movements of the lower orders had comprehensible or 'legitimate' objectives [...] was replaced by the feeling that they aimed at the utter unravelling of society. By the 1830 s and 1840s dread of the 'dangerous classes' could be transformed into near hysteria at times of great social and political tension (Storch, 1975, 62).

The system of social control that had operated for generations in traditional rural communities, where the population had been fairly stable and outsiders were noticed, had blended formal policing with intense scrutiny of the lives of the poor by employers, neighbours and the Church (Neocleous, 2000). In the expanding industrial towns and cities, increasingly characterised by the relocation of those with money to new suburbs away from the overcrowding and stench of old urban cores, the close supervision of the labouring classes by their social superiors and, crucially, the Church (Briggs, 1968), whose ecclesiastical courts had served as a mechanism for imposing discipline over everyday behaviour in previous centuries (Neocleous, 2000), was almost totally absent. Although the factory, with its fixed hours of employment and the wage, provided a new form of discipline, many traditional working practices and non-factory forms of employment persisted until midcentury (Storch, 1977; Cohen, 1979). Moreover, 'the unparalleled discipline [...] of the mill was accompanied by the appearance of free and untrammelled a recreational life as has probably ever existed in England' (Storch, 1977: 142). Such were the fears of the age that there 'was no question of the poor being left to themselves in a state of social laissez-faire' (Donajgrodzki, 1977: 55) so the central conundrum for early Victorian reformers was how best to 'master the masterless' (Neocleous, 2000: 65): to make them work for a living, 
convince them to accept their position in the social hierarchy, discourage them from law breaking and stop their pastimes and traditions from disrupting the smooth operation of the evolving capitalist system - and upsetting the middle class sense of decorum.

Given this situation, it is perhaps no surprise that the first significant intervention finally squeezed by reformers from the laissez-faire state was the creation of the new police, first in London in 1829 and then piecemeal across the country until the establishment of county police forces was mandated by Parliament in 1856 . The new police became the main vehicle for imposing a semblance of control during this early period over a population which had 'not fully experienced industrial discipline' (Cohen, 1979: 129) or compulsory schooling. Whilst rising crime had been mobilised as a justification for police reform in London (Reiner, 2010; Taylor, 1997), policing was orientated around preventative beat patrolling which meant officers were arguably better placed to confront challenges to public order and 'inappropriate' uses of public space than they were criminality. Indeed, Mark Neocleous (2000: 4) observes that police concentrated on 'activities potentially damaging to communal good order' rather than the purely criminal, which in any case tended to be a greater source of public concern at the time than crime as we conceive of it today (Gatrell 1990; Weinberger 1981). This chimes strongly with the argument of revisionist social historians, such as Storch $(1975 ; 1977 ; 1993)$ and Phil Cohen (1979), that the police played a crucial mid-century role in disciplining the working classes by clamping down on their street activities, particularly their leisure pursuits, to the point that many communities saw officers as little more than the repressive arm of the bourgeois state; 'an all-purpose lever of urban discipline' (Storch, 1993: 282) both loathed and resisted.

\section{Ordering public space, disciplining the working classes}

Maintaining order and shaping a working class both suited to the urban industrial economy and whose behaviour was acceptable to the bourgeoisie, whose expectations as regards decorum were much greater than in previous generations (Taylor, 1997), meant curbing two 'inappropriate' uses of public space: informal economic activity and as an all-purpose leisure space. In his work on pre-1850s Portsmouth, Miles Ogborn (1993: 517) argues:

No longer were [the streets] to be a market place for farm animals, a theatre for public entertainments, a shop counter or an impromptu abattoir. Pavements and roads were to be kept clear of all obstruction and dangers, from crowds and cattle to furniture and ferocious dogs. They were to be become arteries 
whose orderly flows of people and goods involved the rationalisation and regulation of the moral behaviour of the streets users.

Not only did costermongers and hawkers, for example, disrupt the smooth flow of traffic in the streets, they were also viewed as something of a throw-back to an earlier time when pilfering goods from the workplace to use or sell as a way of supplementing income was considered the norm. According to Neocleous (2000: 76):

\footnotetext{
The attack on the non-monetary form of the wage and its transformation into a fully-fledged money form meant criminalizing a range of traditional working class activities, bringing them into the orbit of police power and thus legitimising their oppression, a project designed to stamp the authority of private property over the living conditions of the majority of the population and confirm the power of capital as the new master.
}

The suppression of street trading was the cause of many violent confrontations with the police. Costermongers gained a reputation for being especially resistant to attempts to move them on and took pride in assaulting officers for interfering in their livelihood (Storch, 1975).

Whilst some leisure pursuits, particularly fairs and fêtes, were economically troublesome because they precipitated mass absenteeism from the workplace, midVictorian reformers were equally worried by the threat to decorum and what they considered acceptable standards of behaviour posed by street-based leisure. There was also the potential for events causing the working classes to gather in numbers to spill over into protest and violence (Storch, 1977). The police played a significant role in disciplining public working-class leisure but this should not be overstated; some traditional pastimes were abandoned as new indoor leisure opportunities arose and many street cultures faded later in the century as the unskilled and semi-skilled sought respectability and material advancement through the opportunities provided via education, trade unionism and early Labour politics (Cohen, 1979). This notwithstanding, in the middle decades of the nineteenth century the police were given a wide remit to target 'popular activities and recreations considered conducive to immorality, disorder or crime' (Storch, 1993: 286).

Storch's (1993) research into the police as 'domestic missionaries' offers considerable insight into police efforts to suppress working-class leisure pursuits, from animal fights through to the singing of profane songs on the streets and gatherings associated with popular fêtes and festivals. A challenge was also posed to the longstanding freedom of 
assembly on the streets, with men, who had traditionally occupied periods of leisure time hanging around in groups, made to 'move on.' Direct suppression of problem activities often just drove them underground or moved them elsewhere, although this was often considered a successful outcome if thoroughfares were cleared. Fêtes and fairs, held in public and not easily relocated, gave the police opportunities for high profile direct action in a way that activities hidden away behind the closed doors of the public house did not; 'The police proved to be a weapon well-tuned to the task of terminating the popular fête with all its connotations of disorder, drunkenness, sexual license, and property damage' (Storch, 1993: 295). If these, sometimes brutal, confrontations were quite rare the use of physical force by the police to clear the unwelcome from the streets was commonplace (Cohen, 1979). Although middle-class tolerance of violence was waning (Taylor, 1997), it remained a feature of everyday life at this time (Gatrell, 1990) and police officers had few qualms in cuffing boys round the head to convince them to 'move on' (Cohen, 1979).

The Victorian police were aided in their task of curbing acts that had been reconstructed as disruptive or out of place by both new and existing legislation. This 'concerted attempt on the part of the state to criminalize traditional activities which were either recreational or rooted in an alternative economic mode of life and which centred on the street' (Neocleous, 2000: 75) could mean that those who attracted the attention of the police, much like those branded anti-social today, could be behaving in a manner which they considered both reasonable and normal and may, indeed, have previously been legal. A good early example of the narrowing of acceptable street behaviour in London is the Metropolitan Police Act 1839 which encompassed, amongst other things, the permitted hours and licensing of fairs, the outlawing of animal fights for entertainment, restrictions on the driving of cattle on the streets and otherwise obstructing thoroughfares, penalties for what we might call carriage 'joyriding,' discharging a cannon in residential areas, using a dog for drawing a cart, and dumping waste in the streets. Section LIV proscribes various forms of nuisance in thoroughfares, its 17 sub-clauses spanning street entertainment, ferocious dogs, 'furious' carriage driving, riding (a horse) on the pavement, bill posting, hoop rolling, selling of profane or obscene material, soliciting by prostitutes, the throwing of missiles, kite flying and unwarranted door bell ringing.

Just as concerns about street behaviour in Victorian Britain mirrored those of more recent times, so did apprehension about who occupied public space. In the Blair era, it was 
young people whose mere presence or 'hanging around' became discursively associated with anti-social behaviour (Squires, 2006; Crawford, 2009b; Bannister and Kearns, 2012). Although the Victorians had their own hang ups about loitering groups, their bête noir was the vagrant. An apparent unwillingness to work, lack of fixed abode and popular association with petty criminality, ensured the vagrant's place as a folk devil in the Victorian imaginary; the 'epitome of uncivilised self-indulgence' (Jones, 1982: 178). As Caroline Steedman (1984: 56) points out, in addition to being a potential criminal, the vagrant 'represented a mobile anomaly in the structure of social control' that was symbolic of disorder (Neocleous, 2000: 20). Discouraging vagrants from lingering or imposing on them the discipline of the workhouse were favoured solutions made possible by the Vagrancy Act 1824 and later legislation that widened the definition of 'vagrant' and thus 'conferred a statutory and universal power on all policemen in the surveillance of poor people mobile on the roads' (Steedman, 1984: 56).

There was a limit to the ability of the police to suppress unwanted street behaviour due both to manpower availability and the resistance of those being policed. Both Cohen (1979) and Storch (1993) argue that the police quickly learnt to pick their battles carefully and would tolerate certain types of behaviour in some urban spaces that would be suppressed elsewhere. In the longer term, what became much more important to imposing discipline on the streets than the high-profile crackdown was the promise of intervention arising from the 'constant surveillance of all the key institutions of working class neighbourhoods and recreational life' (Storch, 1993: 292). Indeed, Ogborn (1993: 516) argues that the prime objective of police reform in the nineteenth century was to institute 'a police programme which organized authority and information across space to produce a new and systematic surveillance of the city.' The impact of surveillance on street activities may not have been as dramatic as that of direct confrontation but, in Storch's (1993) opinion, it could cause problem behaviour to dwindle over time whilst securing a degree of decorum in the short term. The importance of surveillance and information gathering to the maintenance of order is one of the main refrains of the broken windows argument. Drawing on observations made in the United States, Wilson and Kelling (1982) lament the demise of beat policing precipitated by the switch to patrolling by car. In addition to officers no longer being physically present to deal with disorderly behaviour on the streets, they were also less well informed about what was going on in a neighbourhood. In many respects British 
responses to these concerns in the 2000s - neighbourhood policing, neighbourhood wardens, Police Community Support Officers (PCSOs) - have sought to re-institute street surveillance and knowledge gathering akin to that of the Victorian age.

\section{Beyond disorder: moral failings and disrespect}

Much as the disciplining of the masses in the early Victorian period discussed in this chapter so far reflected middle-class instincts of self preservation in turbulent times and the demand of emerging industrial capitalism for a compliant pool of labour, another crucial motive force was a shift in middle-class values and a concomitant re-calibration of what constituted suitable behaviour in the modern urban age. The Victorian era was notable for the stark social and physical separation of the classes not seen previously (Briggs, 1968; Harrison, 1971). As Friedrich Engels (1999) noted in his famous description of mid-century Manchester, the different classes lived in their own urban enclaves and unless the prosperous needed to enter the city centre for business or entertainment their interactions with the working classes were infrequent and they rarely had need to enter the poorest communities. Indeed, bourgeois concerns about the bankruptcy of working-class culture and leisure pursuits seldom arose out of first hand experience (Harrison, 1971), but was a reaction to what was read in pamphlets and newspapers written by those who had entered the 'terra incognita' of the slums, either to investigate or to evangelise (Walkowitz, 1992). Such physical distance led to the establishment of different social worlds; fêtes and festivals that had once been communal events were recast as boorish and troublesome workingclass pastimes that were no longer welcome (Storch, 1993). Even the public hanging, for so long a showpiece demonstration of justice in action, was moved behind closed doors in 1868 in part at least over concerns about the inappropriate behaviour of the crowds which came to watch and the challenge to Victorian claims of civility posed by death-as-spectacle (Gatrell, 1994).

The Victorian middle class, characterised by piety, sobriety, self-control, thrift and hard work, was generally horrified by the apparent immorality of the working classes (Storch, 1977). Once Chartism had faded and fear of the masses gave way to a more nuanced, if still rudimentary, distinction between the respectable poor and the criminal classes (Gatrell, 1990), considerable efforts were made by reformers, often driven by a sense of Christian duty, to take on a tutelary role, providing moral guidance to the working 
classes (Donajgrodzki, 1977; Storch, 1977). Whilst the State played a role with legislation on, for example, education, child labour and housing, this was the age of the philanthropist, the paternalist and the evangelist. They moved on many fronts, seeking to challenge troubling working class mores by showing them a better way or, to put it less charitably, seeking to impose upon them a 'cultural lobotomy' (Storch, 1977: 139).

The desire of Victorians to remedy not only the behavioural failings of the poor, but also their moral shortcomings might appear to be what differentiates this period from the Blair years, yet this is not the case. Although many of the measures introduced by New Labour to target anti-social behaviour were officially to deter further or more serious deviation from the (locally defined) norm through the threat of criminal sanction, they were also 'designed to signal the unacceptability of ASB' (Bannister and Kearns, 2012: 382) within contemporary society. Furthermore, they fitted into a much wider agenda centred on social values and, essentially, morals. Throughout his time as leader of the Labour Party, Tony Blair continually returned to the Communitarian refrain that with rights come responsibilities to society; 'Respect for others - responsibility to them - is an essential prerequisite of a strong and active community' (Blair, 1996: 237-8; see also Blair, 2010: 78). These twin concerns with respect and responsibility and, most crucially, how to reconstruct them in communities where they were lacking, were to become central to the anti-social behaviour agenda in the 2000s. Anti-social behaviour was emblematic of the decline of respect and, Peter Squires (2006: 151) observes, 'became virtually a metaphor for the condition of contemporary Britain.' Reflecting on this period, Blair (2010: 274) writes that he 'felt we had gone really badly wrong as a society and had to correct it.' The Respect and Responsibility White Paper (Home Office, 2003), which formed the basis for the Anti-Social Behaviour Act 2003, and the Respect Action Plan (Respect Task Force, 2006) discursively aligned renewed action against anti-social behaviour with a project to rebuild respect for others, enforce responsibility and make people behave (Burney, 2005; 2009). Whereas the 'tough on crime, tough on the causes of crime' slogan promised a marriage of the punitive and an attack on the broader structural causes of crime and disorder, the Respect agenda was geared around enforcement (Squires, 2006; Burney, 2009) and fell back on a number of tropes - the dysfunctional family, the flawed individual and inappropriate behaviour as a lifestyle choice (Squires, 2008) - popular in right wing discourse and undoubtedly familiar to Victorians, even if the language used had changed with the passage of time. 


\section{From police to 'social police'?}

The urge to discipline and re-moralise the poor which is evident in the two eras was based on a central unifying factor: a conviction that the State has a crucial role to play in shaping the working class. The laissez-faire State was in many respects an unwilling participant for much of the nineteenth century, quite content to leave moral reform to industrial paternalists, housing charities, evangelical Christians, the temperance movement and antiprostitution campaigners. But many influential thinkers persistently argued that the masses needed direction and it was the duty of their social betters to provide it. Writing at the time of the Chartist protests, Thomas Carlyle (1998: 161) observed:

Bellowings, inarticulate cries as of a dumb creature in rage and pain; to the ear of wisdom they are inarticulate prayers: 'Guide me, govern me! I am mad, and miserable, and cannot guide myself!' Surely of all 'rights of man', this right of the ignorant man to be guided by the wiser, to be gently or forcibly, held in the true course by him, is the indisputablest.

Whereas Carlyle favoured leadership by an authoritarian figurehead, others sought to mould the working classes through an all encompassing system of what Donajgrodzki terms 'social police,' characterised 'by a belief that a strong tutelary grasp should be maintained over the poor' (1977: 52). Today the domain of the police is limited to crime control and order maintenance but, early in the nineteenth century, reformers such as Patrick Colquhoun and Edwin Chadwick conceived of the system of police as being a far reaching disciplinary apparatus, combining what we now view as policing with many aspects of what we would classify as social policy. To their mind, to police meant the 'good ordering of society' (Neocleous, 2000: 41; see also Ogborn, 1993: 507) and this entailed addressing the perceived failings of the working classes in totality, rather than simply focusing on their disorderly conduct. Indeed, Donajgrodzki (1977: 71) asserts that Chadwick proposed a system of tutelary control so comprehensive that it would entail a 'merciless assault on a very widely defined range of deviant activities' including, rather like a CRASBO, limitations on the movements of ex-offenders through public space. Early reformers were convinced that 'the preservation of order must include not only consideration of legal systems, police forces and prisons, but of religion and morality, and of those factors which supported or propagated them - education, socially constructive leisure, even housing and public health' 
(Donajgrodzki, 1977: 52). Such a monolithic system of police was far too anti-libertarian to ever be realised at that time and instead State intervention proceeded piecemeal with the definition and role of police greatly narrowed (Neocleous, 2000), the workhouse tasked with reinforcing the discipline of labour, and moral reform relying on a mixed economy of the State, motivated individuals, charitable groups and the non-conformist churches.

\section{Concluding comment}

Early Victorian reformers and New Labour were motivated by context-specific social problems and developed their own equally high profile and controversial solutions to remedy them. Nevertheless, what echoes across the ages is the desire to regulate public behaviour, maintain order and enforce moral improvement on the most worrisome elements of the working class. As such, the Blair government's attempts to curb anti-social behaviour, enforce responsibility and rebuild respect can be read as part of an ongoing disciplinary project rather than a wholly new departure. However, New Labour's willingness to impose strict controls over behaviour that was nuisance rather than criminal and to mobilise the power of the State against those who refused to desist from anti-social behaviour or accept their responsibilities to wider society signalled a transition to an arrangement more akin to 'social police' than the laissez-faire Victorian state could countenance; one in which the criminal justice system was afforded a greatly enhanced tutelary role at the expense of other branches of social policy (see Wacquant, 2001; Rodger, 2008 for a discussion of this inversion). Although the heat has gone from the rhetoric surrounding anti-social behaviour and the Respect agenda was short lived, the enhanced powers to confront these phenomena that the state acquired during the 2000 s remain and their reform in 2014 (as a consequence of the Anti-social Behaviour, Crime and Policing Bill) has the potential to give new life to the disciplinary project. 


\section{References}

Bailey, Victor. (ed.) (1981). Policing and Punishment in Nineteenth Century Britain. London: Croom Helm

Bannister, Jon, and Kearns, Ade. (2012). 'Overcoming Intolerance to Young People's Conduct: Implications from the Unintended Consequences of Policy in the UK.' Criminology and Criminal Justice, 13(3): 380-97.

Blair, Tony. (1996). New Britain: My Vision of a Young Country. London: Fourth Estate.

Blair, Tony. (2010). A Journey. London: Hutchinson.

Briggs, Asa. (1968). Victorian Cities. London: Pelican Books.

Burney, Elizabeth. (2005). Making People Behave: Anti-Social Behaviour, Policy and Politics. Cullompton: Willan Publishing.

Burney, Elizabeth. (2009). 'Respect and the Politics of Behaviour.' In Securing Respect: Behavioural Expectations and Anti-Social Behaviour in the UK, edited by Andrew Millie, 23-40. Bristol: The Policy Press.

Carlyle, Thomas. (1998). 'Chartism.' Extract reprinted in The Victorian Age: An Anthology of Sources and Documents, edited by J. M. Guy 155-166. London: Routledge. Originally published London: James Fraser, 1840.

Centre for Social Justice (CSJ). (2012). Time to Wake Up: Tackling Gangs one Year after the Riots. London: CSJ.

Cohen, Phil. (1979). 'Policing the Working-Class City.' In Capitalism and the Rule of Law, edited by National Deviancy Conference, 118-136. London: Hutchinson \& Co.

Crawford, Adam. (2009a). 'Governing Through Anti-Social Behaviour: Regulatory Challenges to Criminal Justice.' British Journal of Criminology, 49(6): 810-31.

Crawford, Adam. (2009b). 'Criminalizing Sociability through Anti-Social Behaviour Legislation: Dispersal Powers, Young People and the Police.' Youth Justice, 9(1): 5-26.

Donajgrodzki, A.P. (1977). "Social Police' and the Bureaucratic Elite: a Vision of Order in the Age of Reform.' In Social Control in Nineteenth Century Britain, edited by A.P. Donajgrodzki, 51-76. London: Croom Helm.

Donajgrodzki, A.P. (ed.) (1977). Social Control in Nineteenth Century Britain. London: Croom Helm.

Engels, Friedrich. (1999). The Condition of the Working Class in England. Oxford: Oxford University Press. 
Garland, David. (1996). 'The Limits of the Sovereign State: Strategies of Crime Control in Contemporary Society.' British Journal of Criminology, 36(4): 445-71.

Gatrell, V.A.C. (1990). 'Crime, Authority and the Policeman-State.' In The Cambridge Social History of Britain 1750-1950, Volume 3: Social Agencies and Institutions, edited by F.M.L. Thompson, 243-310. Cambridge: Cambridge University Press.

Gatrell, V.A.C. (1994). The Hanging Tree: Execution and the English People 1770-1868. Oxford: Oxford University Press.

Guy, J.M. (ed.) (1998). The Victorian Age: An Anthology of Sources and Documents. London: Routledge

Hadfield, Phil. (2006). Bar Wars: Contesting the Night in Contemporary British Cities. Oxford: Oxford University Press.

Harrison, J.F.C. (1971). The Early Victorians 1832-1851. London: Weidenfeld and Nicolson.

Home Office. (2003). Respect and Responsibility - Taking a Stand Against Anti-Social Behaviour. London: The Stationery Office (TSO).

Jones, David. (1982). Crime, Protest, Community and Police in Nineteenth-Century Britain. London: Routledge and Kegan Paul.

Lawless, Paul, and Brown, Frank. (1986). Urban Growth and Change in Britain: An Introduction. London: Harper and Row.

Millie, Andrew. (2009). Anti-Social Behaviour. Maidenhead: Open University Press.

Millie, Andrew. (ed) (2009). Securing Respect: Behavioural Expectations and Anti-Social Behaviour in the UK. Bristol: The Policy Press.

Ministry of Justice. (2013). Statistical Notice: ASBO Statistics - England and Wales 2012. Accessed 14 December 2013, (https://www.gov.uk/government/uploads/system/uploads/attachment_data/file/25 3535/Anti-Social_Behaviour_Order_Statistical_Notice_2012.pdf)

Minton, Anna. (2009). Ground Control: Fear and Happiness in the Twenty-First Century City. London: Penguin Books.

Morris, R.J. and Rodger, Richard. (eds.) (1993). The Victorian City: A Reader in British Urban History, 1820-1914. London: Longman.

National Deviancy Conference. (ed.) (1979). Capitalism and the Rule of Law. London: Hutchinson \& Co. 
Neocleous, Mark. (2000). The Fabrication of Social Order: A Critical Theory of Police Power. London: Pluto Press.

Ogborn, Miles. (1993). 'Ordering the City: Surveillance, Public Space and the Reform of Urban Policing in England 1835-56.' Political Geography, 12(6): 505-21.

Reiner, Robert. (2010). The Politics of the Police, $4^{\text {th }}$ edition. Oxford: Oxford University Press.

Respect Taskforce. (2006). Respect Action Plan. London: Home Office.

Rodger, John. (2008). Criminalising Social Policy: Anti-social Behaviour and Welfare in a Decivilised Society. Cullompton: Willan.

Squires, Peter. (2006). 'New Labour and the Politics of Anti-Social Behaviour.' Critical Social Policy, 26(1): 144-68.

Squires, Peter. (2008). 'The Politics of Anti-Social Behaviour.' British Politics, 3(3): 300-23.

Steedman, Caroline. (1984). Policing the Victorian Community: the formation of English provincial police forces, 1856-80. London: Routledge and Kegan Paul.

Storch, Robert. (1975). 'The Plague of Blue Locusts: Police Reform and Popular Resistance, 1840-57.' International Review of Social History, 20(1): 61-90.

Storch, Robert. (1977). 'The Problem of Working-Class Leisure: Some Roots of Middle-Class Moral Reform in the Industrial North: 1825-50.' In Social Control in Nineteenth Century Britain, edited by A.P. Donajgrodzki, 138-162. London: Croom Helm.

Storch, Robert. (1993). 'The Policeman as Domestic Missionary: Urban Discipline and Popular Culture in Northern England, 1850-80.' In The Victorian City: A Reader in British Urban History, 1820-1914, edited by R.J. Morris and Richard Rodger, 281-306. London: Longman.

Taylor, David. (1997). The New Police in Nineteenth-Century England: Crime, Conflict and Control. Manchester: Manchester University Press.

Thompson, F.M.L. (ed.) (1990) The Cambridge Social History of Britain 1750-1950, Volume 3: Social Agencies and Institutions. Cambridge: Cambridge University Press.

Walkowitz, Judith. (1992). City of Dreadful Delight: Narratives of Sexual Danger in LateVictorian London. London: Virago.

Wacquant, Loïc. (2001). 'The Penalisation of Poverty and the Rise of Neo-Liberalism.' European Journal of Criminal Policy and Research, 9(4): 401-12. 
Weinberger, Barbara. (1981). 'The Police and the Public in Mid-Nineteenth Century Warwickshire.' In: Policing and Punishment in Nineteenth Century Britain, edited by Victor Bailey. London: Croom Helm.

Wilson, James Q., and Kelling, George. (1982). 'Broken Windows: The Police and Neighbourhood Safety.' The Atlantic, 1 March,

(http://www.theatlantic.com/magazine/archive/1982/03/broken-windows/304465)

\section{Legislation}

Anti-Social Behaviour Act 2003

Clean Neighbourhoods and Environment Act 2005

Crime and Disorder Act 1998

Metropolitan Police Act 1839

Police Reform Act 2002

Vagrancy Act 1824

\footnotetext{
${ }^{1}$ See Squires, 2006; Minton, 2009; Crawford, 2009a for discussion of the concentration of New Labour's ASB policy on the behaviour of the socio-economically marginalized.

${ }^{2}$ In 2007 Fiona Pilkington killed herself and her severely disabled daughter following a long period during which they had been the targets of constant verbal harassment and abuse and had objects thrown at their home by local youths. Despite 30 reports about their victimisation to the authorities over a 10 year period including 13 in the year prior to their deaths, no significant steps were taken to deal with the situation as either a case of anti-social behaviour or disability hate crime.

${ }^{3}$ Blair (2010) credits Gordon Brown as having coined this phrase during one of their policy discussions in the USA in the early 1990s.
} 